less than a year: two of these patients have organic brain syndromes and two are schizophrenic. We have no access to a mental hospital or similar long-stay facility but one patient from the district has been in a private hospital for over a year and another has been transferred from a special hospital to a mental hospital in a neighbouring county.

Follow-up of all discharges ${ }^{1}$ has shown that, over a six year period, 17 patients have had continuous stays lasting more than a year (seven organic, five affective and five schizophrenic). Of these three are dead, two were transferred to the dementia unit and others have been resettled at home, in hostels or private nursing homes in circumstances which seem adequate and appropriate.

These figures are substantially lower than those quoted by Dr Haslam but comparable with the 20 patients from a population of 230,000 accumulated over 11 years meeting criteria for admission to a Manchester Hospital Hostel ${ }^{2}$ Obviously further investigation is required to establish whether the service is indeed meeting patients' needs and whether a substantial number drift out of contact. With regard to the latter point we have continuing contact through community and day services with $75 \%$ of our discharged patients diagnosed as schizophrenic.

This pattern has emerged from a small industrial town and its environs in which $90 \%$ of the population live within four miles of the hospital. We also have the advantage of a wide range of resources planned under the Worcester Development Project (rehabilitation hostel, day hospital, day centre, community nurses and mental health social workers). One should be cautious about extrapolating conclusions to different catchment areas, particularly large cities. Nevertheless we are concerned that unwarranted pessimism about the possibility of community care may result in perpetuating the existence of large out-moded institutions, locking up large amounts of money and resources which urgently need diversion to progressive psychiatric services.

J. A. ROBERTSON

R. E. LAWRENCE

S. CUMElla

Kidderminster General Hospital

Kidderminster, Worcs

REFERENCES

'Cumella, S., Lawrence, R. E. \& Robertson, J. A. (1986) The ex-long-stay (in preparation).

${ }^{2}$ Goldaerg, D., Bridges, K., Cooper, W., Hyde, C., Sterling, C \& WyatT, R. (1985) Douglas House: A new type of hostel ward for chronic psychotic patients. British Journal of Psychiatry, 147, 383-388.

\section{Human volunteers in pharmacological experiments}

Dear Sirs

An interesting debate has started in the Republic of Ireland as to the question of healthy human volunteers being used in pharmacological experiments. I would like to put forward a few points.
(1) Subjects should be fully informed of all the known side-effects in language which he can understand and which is free from unintelligible jargon.

(2) The subjects' motives should be carefully assessed before being admitted to the study-the chance of personal gain should in my opinion exclude the subject.

(3) All evidence, and results of such experiments should be available for scrutiny by the subjects or their representative for ten years after the research is complete.

It may be of interest to your readers to know that a medical student at one famous London teaching hospital was involved in just such experiments, and due to pressure being applied he had no option but to repeat the procedure without being given the opportunity to reveal the sideeffects of the drug given in the first experiment.

He subsequently failed his finals repeatedly, was admitted to hospital himself five times, and was on medication for almost 18 years. Whether this was the only factor in his illness is not known, for sure. However, it underlines the point that pharmacological experiments can be extremely dangerous not only for the researcher, but for the subject. I would put in a plea for stronger safeguards in the future.

P. M. QUINN

The Women's Health Centre,

Cork, Ireland

\section{Peer group counselling - appeal for help}

\section{Dear SirS}

At the beginning of May an interesting and useful initiative will be getting off the ground in the Greater London area. For the past six months a group of young people has been undergoing training in peer group counselling-and another group in problem solving - in the field of drug misuse. In May they will be ready to start working together in teams of two under the auspices of the Association for Prevention of Addiction (APA).

However, the psychiatric registrar who was going to conduct the supervision group has had to withdraw for family reasons and we are left with this gap. It is of first importance that someone-a psychiatrist or a psychotherapist - takes this group regularly every week because it will be necessary to keep the counsellors on course and the advisers supported in the difficult area.

I am appealing for someone used to group work to come forward and do this vital job. The APA teams themselves will be working voluntarily, with only their expenses being paid, out of their wish to do their best for society.

Although they are young and inexperienced their training will have gone a long way towards preparing them for working with drug takers, problem drug misusers, their families and friends. But there are bound to be occasions when they will be uncertain whether the interventions they have made during a session with a client have been the most likely to advance the process or even been appropriate. 
To be sure that the counselling process is effective, supervision after a session is essential. Such supervision is best undertaken in a group, so that other members of the APA teams will be able to profit from the teaching as well.

If a psychiatrist or psychotherapist would like to join this exciting venture of bringing barefoot psychiatry into the community in a field notoriously lacking in resources please contact me as soon as possible. I must add that I am not yet sure whether it will be possible to pay an honorarium to the therapist who volunteers to take on this responsibility, but we are currently appealing for funds for this and I have good hopes of a positive response.

Dale Beckett Please reply to: Dr Dale Beckett, APA, 56 New Oxford Street, London WCIA IES.

\section{Violent videos}

DeAr SirS

Professor Sims and Dr Melville-Thomas (Bulletin, December 1985, 9, 238-240) mention that the research of which their own study formed a part 'was clearly politically sensitive'. One can only agree that there are obvious dangers in associating scientific research with campaigns, particularly when there is insufficient time to attempt more than a superficial study-although I have no hesitation in giving due deference to the opinion of colleagues working in child and adolescent psychiatry.

The impetus for the research described and cited in the Bulletin came from an informal group within which it was decided to sponsor an enquiry privately funded by individuals and the Churches. The description 'a Parliamentary Group Video Enquiry' could be considered misleading as the group was not an official representative Parliamentary sub-committee with a brief to inform. Dr Clifford Hill (sociologist) agreed to direct the enquiry and produce proposals for research. It was later decided to set up an academic working party to implement these ideas and in July 1983 a list of names was approved which included those of Professor Sims and Dr Melville-Thomas as medical members. In the same month Mr Graham Bright had announced the intention to introduce a Bill to control the availability of video films. ${ }^{1}$ Dr Hill notes that it was decided to keep the Academic Working Party entirely separate from the sponsoring body and from any political or campaigning influence. The methodology and aspects of the subsequent reports relating to children's patterns of viewing (Video Violence and Children, Parts $I$ and $I)^{2,3}$ have been criticised in a book ${ }^{4}$ edited by Martin Barker (Senior Lecturer, Communication Studies) and elsewhere.

Dr Hill has commented on the significance of these reports in the following terms: '.. a turning point in the life of this nation. This battle that we are in now is not just against flesh and blood as the Bible says but it is against the principalities and powers that are attempting to sweep this country into the moral sewer that is beginning to flow through this Nation to sweep us towards destruction... but I believe you know that God is sounding a trumpet call if you like to the Christians in this Nation, to enter into battle for the spiritual and moral soul of this nation. What we need to remember though is that it is not our battle, but it is God's battle'.

Reference to the work described by Professor Sims and Dr Melville-Thomas appeared in the popular press, also in florid style, for example: 'Violence fuelled by Video Nasties'.. 'Video nasties are poisoning the minds of Britain's teenagers. According to experts, rioters and child batterers are typical of a generation fed on a diet of pornography and violent videos ... and the next generation could be overwhelmed by the revolting diet of sexual horror and brutality'. ${ }^{6}$ This conclusion is somewhat at variance with that drawn from case studies within psychiatry: '. . our findings based on the cases given to us merely hint at what effects might be happening in children and adolescents, particularly those of vulnerable disposition'.?

The political consequences of that contemporary mood-in the form of a Bill with the potential power of censorship (Governmental) well beyond that necessary to deal with images of violence of the type described-is now with us. It remains to be seen how it will be interpreted.

Presumably few will mourn the loss of nasty videos or wish to have the risk of children in general being exposed to them. The issue is where such matters can be placed in a hierarchy of stressors and how its availability should be influenced. Academics have an important function in clarifying the issues involved, to comment, perhaps, on anomalies, hypocrisy, and the history of the over-valued idea, and to dissociate themselves with reason from the unsupportable.

I have never seen a nasty video.

9 Sunningdale Drive

D. H. BOWKER

Bramhall, Stockport

Cheshire

\section{REFERENCES}

'BrIGHT, Graham (presenter) (1983) Video Recordings: A Bill to make provisions for regulating the distribution of videos and for connected purposes. Bill 14. 301448. 49/1. London: HMSO.

${ }^{2}$ HiLL, C. (1983) Video Violence and Children: Part I. Children's Viewing Patterns in England and Wales. A Report of a Parliamentary Group Video Enquiry. London: Oasis Projects.

3 _- Davis, H., Holman, R. \& Nelson, G. (1984) Video Violence and Children: Part II, Children's Patterns and Parental Attitudes in England and Wales. A Report of a Parliamentary Group Video Enquiry. London: Oasis Projects.

'BArker, Martin (ed.) (1984) The Video Nasties, Freedom and Censorship in the Media. London: Pluto Press.

'BBC, Radio 4, Interview, "Sunday", 26 February 1984.

-Daily Mail, 17 October 1985, page 9.

'Barlow, G. \& HiLh, A. (eds) (1985) Video Violence and Children. Sevenoaks: Hodder \& Stoughton. 